\title{
Is industrial property law a catalyst for inequality? Instruments for a holistic legal-economic development
}

\author{
¿Es el derecho de propiedad industrial un catalizador \\ de la desigualdad? Instrumentos para un desarrollo \\ jurídico-económico holístico
}

\author{
Raúl Alexander Velasco Chávez \\ Independent legal researcher \\ City: Quito \\ Country: Ecuador \\ Original article (miscellany) \\ RFJ, No 8, 2020, pp. 223-247, ISSN 2588-0837
}

\begin{abstract}
This note goes around the role of industrial property. Furthermore, it shows some arguments from the philosophical and socio-political perspective. The emerging questions seek to discuss whether or not the casuistic analysis determines if the Law denotes a hypotactic behaviour towards capital or whether it would be appropriate to define the Law (of Intellectual Property) as a new expression of capitalist servility.
\end{abstract}

KEYWORDS: Intellectual property, industry property, capitalism, capitalist systems, market economy, politics

RESUMEN: Esta miscelánea tiene como objetivo reflexionar entorno a las relaciones centrales entre el derecho de propiedad industrial y el desarrollo, entendido desde una acepción holística. En la primera sección se discuten algunas generalidades respecto a la propiedad intelectual que serán de gran utilidad instrumental a lo largo del escrito. En la segunda sección se explican los recursos metodológicos empleados, el alcance de la investigación, los usos de fuentes y las aproximaciones cognitivas que se pretenden alcanzar. En la 
tercera sección se presenta una síntesis de los resultados a los que se ha arribado mediante la investigación. A continuación, se discuten los resultados presentados y se reflexiona acerca del cumplimiento de la hipótesis. Finalmente, se esboza un corolario y el planteamiento de nuevas interrogantes derivadas de esta indagación preliminar.

PALABRAS CLAVE: Propiedad intelectual, propiedad industrial, capitalismo, economía de mercado, economía de mercado, política

\section{INTRODUCTION}

"Civil law serves to rob the rich of the poor. Criminal law serves to prevent the poor from stealing from the rich." This French aphorism compiled by Mayol (2017) elucidates what authors of heterodox currents, such as Althusser (1970), would verbalize as the subordination of the legal dimension to the interests of the ruling class. In this sense, this research on the role of the industrial property could be initiated by asking: Are there new actors in the contemporary era that pluralize and abstract the already mentioned ruling class? Can case-law analysis determine that law has a hypotactic behavior toward capital? Moreover, finally, would it be correct to define Intellectual Property Law as the most natural expression of capitalist servility?

This miscellaneous article aims to conjecture the central relations between industrial property law and development, understood from a holistic point of view. The first section will discuss some generalities regarding intellectual property that will be of great instrumental use throughout the writing. The second section will explain the methodological resources used, the scope of the research, the uses of sources, and the cognitive approaches that intended to be achieved. The third section will present a summary of the results reached through the research. The fourth section will discuss the results presented and reflect on the fulfillment of the hypothesis. Finally, the last section will 
be reserved for the outline of a corollary and the raising of new questions arising from this interdisciplinary inquiry.

Having shown the structure of the present research, we will give way to the exposition of some research and legal generalities that will help the reader to understand better and interpret the results and decisions that will emerge in the following paragraphs.

As an introductory basis, it will be worth limiting the understanding of each of the concepts that are developed in the title of the research. On the one hand, the Chilean Institute of Intellectual Property defines Intellectual Property as a branch of law that seeks to encourage innovation, creation and technology transfer, while regulating the organization of the markets for certain intangible assets. With a high degree of concordance, the World Intellectual Property Organization (WIPO, s.f, p.2) gives a similar definition and additionally adds to the dichotomy industrial property-copyright as the taxonomy of the quintessential branch. Within the line of WIPO's ideas, this research focuses on the analysis of regulation within the industrial property, being the patents, the marks, and the industrial designs the primary units of analysis of the work. On the other hand, inequality applied to society will be understood from the perspective of Bregman (2017, p.55), postulating it as a negative social situation in which an individual or group of individuals enjoy certain qualities, quantities, or circumstances favorably diverse concerning others, usually from illegitimate situations. Finally, what is understood as a holistic legaleconomic development will be defined? From the critical perspective of the Orthodox economy, holistic development is understood as the progress of society. It leads societies towards a stage where its needs are met to a greater extent than at a previous stage and satisfaction variables cover a multiplicity of dimensions ( economic, cultural, social, participatory, degrees of freedom, among others) that encompass the complexity of human coexistence with their environment and their peers (Valcárcel, 2006). 
To conclude this section, we will discuss some budgets needed for a comprehensive understanding of research. First, it is clarified that research is not essentially philological or epistemological, so far from genealogical methods or the archeology of words (Foucault, 1981), there will be a full acceptance of words and logical constructions, which will be raised. Second, the deontological questioning of intellectual property will coexist with its ontological development. Therefore, the most advanced philosophical questions regarding the origins of society and the justification of property itself will be treated tangentially, as they exceed the scope of this research. Finally, accepting the complexity of coining generalizable definitions will limit the study to the discussion regarding the understanding of the variables in the terms defined in the preceding paragraphs.

\section{METHODOLOGICAL ASPECTS}

From the constructivist assumption that absolute truth is unattainable by human beings and the best epistemological aspiration is relative (intelligible) truth within delimited parameters; The methodology of this work is defined as eclectic, as it encompasses a significant diversity of cognitive approach methods. Following Leavy (2014), Gerring (2004), and Hernández (2014), the compatible research classifications have been taken among these authors and as the methodological taxonomy for this miscellaneous. From the type of inference, the work is descriptive, since, for the formal logic, it does not manage to show the causality of the arguments in a strict sense. From the method, the research is mixed, as it takes qualitative arguments (from case studies) to quantitative demonstrations (reproduced from other academic works). From the purpose of the research, this is mixed; that is to say, both confirmatory (since it tries to evaluate if the orthodox theories concerning the concretion of the regulation of the intellectual property have been sufficient) and exploratory (because it tries to construct the bases of a legal theory of the intellectual property 
congruent with the case Ecuadorian). The temporal variation is diachronic since the evaluation of the policies related to intellectual property is done in different periods in each case. The analysis method is comparative, as it evaluates various units of analysis in different periods. From the method of inquiry, this research is theoretical, since no empirical studies are generated. According to logical rules, the research is deductive, since it adopts general rules and abstract theories until concrete cases (passage of general to particular). Finally, in terms of obtaining the data, these are from exogenous sources and by different sources, as information is not collected autonomously by direct means with the units of analysis.

\subsection{Presentation of results}

After having made the main clarifications regarding the scope of the research and the method used. We will proceed to the presentation of the main results divided into four subsections:

a)The countries in development, to a lesser extent, ensure industrial property than developed countries.

b) Increasing Industrial Property Rights is highly correlated with more significant economic growth.

c) In Ecuador, the State should encourage investment in research with a common approach to knowledge.

d) There is a high correlation between the protection of Intellectual Property rights and innovation.

\subsubsection{Developing countries secure industrial property to a lesser extent than developed countries}

Tejedor, R. Gil, M. \& Tejedor, J. (2016) show with an econometric model that developing countries tend to protect property rights to a lesser extent than developed countries, with a high correlation between this premise and that which argues that developing countries invest in Innovation and 
Development (in percentage and absolute terms) a lower amount than developed and industrialized countries.

Similarly, patents in the industrial sector are applied to a greater extent in buoyant economies (such as China, Japan, and Asian tigers) than in developing economies (such as China). South American or African).

The presentation of data from the World Intellectual Property Organization (WIPO) corroborates what was stated in the previous paragraph. The economies that apply for patents (See Graph 1) and enact more incisive legislation (See Graph 2) are the most developed countries or those economies that have sustained and emerging growth. It corroborates the premise that patent protection occurs when the technological stock is comparatively larger.

Graph 1: The ten largest patent applicators in the world

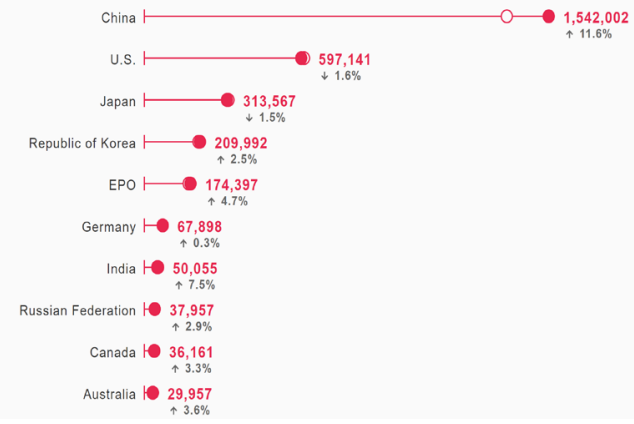

Source: OMPI (2019)

Graph 2: The ten most significant users of the PCT system (Patent Control Treaty) 


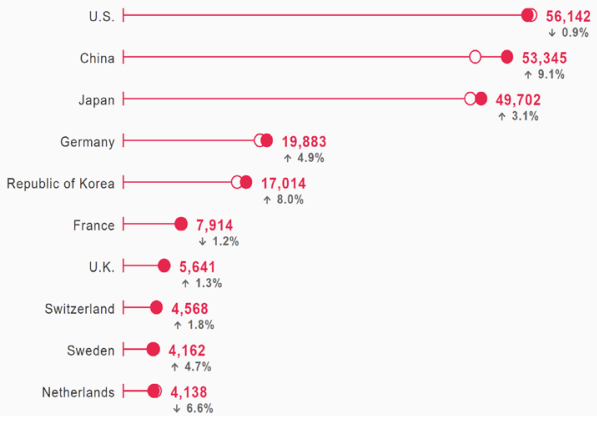

Source: OMPI (2019)

\subsubsection{Increasing Industrial Property Rights is highly correlated with higher economic growth}

This premise is primarily nourished by the graphs in the previous section, as these explain that the list of countries that most defend industrial property and the use of patents are those that generally have better performance in terms of macroeconomic. In a simulation conducted for the Microsoft company, an increase in intellectual property records would lead to growth in Gross Domestic Product (GDP), investment, trade, domestic consumption, tax collection, and research spending; however, it should be borne in mind that in this simulation unemployment and inequality increased, which linked to the previously introduced concept of holistic development means a contingent and case-dependent outcome, as will be discussed in later sections.

For this premise, it is critical to understand that the correlation does not show causality, so spurious relationships are left open. The premise is true. However, the widespread increase in per capita income and the vast technological advances in various contexts could be other causes that explain this correlation, and the protection of Industrial Property rights is not the leading cause of that. 
On the other hand, a high negative correlation between hours worked, and productivity in higher-income countries shows that technology can contribute to improved living conditions in multiple contexts. This graph allows us to conclude that technological progress brings with it a reduction in the working day and thus an increase in the use of consumers and an increase in leisure time ceteris paribus. When finding this relationship and increasing such technology thanks to the development of Intellectual Property law, the premise introduced here becomes valid.

Regarding the role of the State in Ecuador and the optimization of regulations in a logic of social justice and knowledge generation, both official bodies (Senescyt) and various national (Pazos, 2016) and international (Chang, 2016) actors have seen with approval the issuance of the Organic Code of the Social Economy of Knowledge (commonly known as the "Codigo Ingenios"). The central arguments regarding the need to issue regulations other than the regulations enacted by the most developed countries are the technological disadvantage that generates temporary backwardness, the pool of knowledge not patented by native peoples, and opportunity costs to individual social indicators product of the excessive protection of industrial property rights. However, after an exhaustive bibliographic review and observing a multiplicity of multilateral evaluations, the result reached is that the promulgation of the conspicuous "Codigo Ingenios" has not represented a quantitative leap to a knowledge economy or technology-intensive.

The importance of generating an intellectual property right that promotes holistic and cultural context-dependent development, without focusing on the premise that the protection of Intellectual Property effectively produces innovation, can be justified, from an empirical point of view, in the weak correlation between income and social problems.

Finally, as a result of this section, it is stated that there is a clear relationship between social problems and inequality, 
which shows that any Industrial Property protection policy that seeks to have positive results in terms of holistic development must to collaborate with the reduction of the inequality and with the concordance of constitutional principles that in the Ecuadorian society are defended so much.

With robust econometric models and complicated equations, Gómez-Valenzuela (2018), Tejedor, R. Gil, M. \& Tejedor, J. (2016) and The Competitive Intelligence Unit (2011) substantiate from economic regressions the authentic relationship between the protection of intellectual property rights and innovation; in this way, the possibility of spurious correlations from the methodology used by the same is annulled.

This section only mentions proxy variables for the protection of intellectual property rights, so the analysis has a clear bias in agreement with each author. Its scope is fundamentally quantitative, with a marginal qualitative inference that works best in other sections. What can be assured with greater certainty is that spending on Investment and Development (R\&D) is highly correlated with patent registration.

\section{THEORETICAL DISCUSSIONS AROUND THE RESULTS}

Having presented the main results reached through this research, we will continue to discuss several controversial aspects that emerged as angular inputs of the selection of data and premises set out in the previous section.

\subsection{Evaluation of the industrial property protection approach}

This section of the discussion will evaluate the two main approaches since Boyle (2003) and Castro (2009) defend industrial property: the protection of industrial property with a capitalist approach and the social economy of knowledge.

On the one hand, the capitalist approach considers it essential to defend knowledge as a private good and to endow it 
with that character. Similarly, this approach weighs the market value and believes in the patent transaction as another asset. The central idea of this approach is to weigh profit over equity and efficiency over distributive equality. In this approach, the distribution of income is irrelevant, and the fundamental thing is the increase in the profit on the part of the investors.

The social economy of knowledge is strongly opposed to such privatization and views knowledge as a public good. This approach is more instrumentalist and looks at knowledge as a tool for achieving collective progress inequity and social justice. This approach insists on the positive externalities of knowledge and therefore engages in the collaborative production of knowledge and ideas that Acemoğlu (2012) would call spillover effects. For this approach, knowledge is neither exclusive nor rival, so disseminating it can only have positive effects.

Without a research bias on either approach, this research will discuss some of the more relevant practical aspects of both. It should be clarified that the philosophical, sociological and economic discussion regarding the origins of private property, the original accumulation of capital, systemic spoils, Speen Hamland 1795, the law of enclosures, the tragedy of the anti-commons, exploitation, alienation, alienation, and reification that the capitalist system performs in its actors, as argued by Bourdieu (2001) or Polanyi (1992) transcend the scope of this research, so instead of opting for one of the two currents what will be done is to proceed with eclecticism in the points of the best explanation of each of them.

Something that must be stated in this section is whether knowledge is generated from individual genius or from complex cultural accumulation, which has not been resolved by the social sciences and will continue to be a scientific question. Although this discussion seems minor, it is significantly far from it, as the answer to that could shed light on whether making property rights more restrictive is optimal and fair. Without reaching an unambiguous answer, some utilitarianism, or pragmatism, must 
be sought, which momentarily excludes this relevant issue to seek the duty of legal-economic management in intellectual property matters.

If in the previous sections, we talked about the results that connected research and innovation with development (without this necessarily being a holistic development), the question to be asked would be: How to achieve that research and innovation? Although the orthodox recipe has dictated that it is through market liberalization, Ha Joon Chang (2002) has shown that history is far from saying what will be seen in the next paragraph.

One of the founding drivers of this research was whether industrial property protection increased the value of companies for the Ecuadorian context. In that sense, it is shown from three different models (See the first subsection of the Results section) that this is fulfilled; however, there is another version of European cases that can be contrasted with that. In his text A Kick to the Stairs (2002), Chang questions traditional history and explains that there may have been events that moved away from the free market as successful cases. Chang (2001) argues that industrial property encourages costly litigation, reduces the resources available for investment in $R \& D$, discourages the development of new inventions when the inventor enjoys the monopoly of his invention and can live on that income. The social optimum by restricting a seemingly unlimited good, diverting activities to other patentable ones (although they may be less useful), creates high costs by encouraging minimal and useless adjustments to patent, creates legal barriers that restrict competition, and goes against the human principles of cooperation. In that opposition, in the 2002 text mentioned above, Chang cites Switzerland and the Netherlands as examples of economic development far removed from patents. Chang argues that Dutch economic performance improved from 1869 to 1912, where he repealed his patent law (started in 1817). Similarly, in Switzerland, opposition to patent implementation until 1907, according to Chang, promoted the 
country's development and allowed it to acquire ideas from Germany and thus increase foreign investment in its industries (something severely punished today).

\subsection{Evaluation of industrial property in a historical sense and a regional evaluation}

The Orthodox creed has argued that the protection of intellectual property has been inherent in the development, the question to be asked in this section is: has this been true? In 1883 the Paris Convention for the International Protection of Industrial Property emerged, 1891 began the Madrid arrangement that allows the addition of protection mechanisms from bilateralism. With international trademark registration, 1970 is born in shape what is known today as a World Intellectual Property Organization. In 1974 this body was part of the United Nations (WIPO, 2019). This count is important because it seems that the protection of Industrial Property has brought economic development par excellence, but this is, according to Anguita (2016), Boldrin \& Levine (2008), and ECLAC (2008), at least questionable.

The existing dichotomy between Import Substitution Industrialization (ISI) and free trade theory has been closely linked to the discussion around intellectual property. Patent protection has always been at the forefront of free trade negotiation agendas, and related clauses were crucial for limiting regional development under that model. Where does the aporia of this link between free trade conditions and patent protection lie? The answer is exceptionally intuitive and is in a double moral standard. As Machlup and Penrose (1950) argue, the most developed countries generated strong protectionism in their industries. In the first instance, they were opposed to allowing extensive patent protections until they had a technological heritage that had the advantage of other countries. Then, the moment in which in an ideal way, they executed the instruments of protection, and they became staunch defenders 
of the protection of the patents and the rights of Industrial Property.

As explained in the previous paragraphs, it would seem that the periphery countries are quartered in legal systems that help their development and manage to make forced technological transfers as Switzerland did at the time, but there is nothing more than reality. Decision 291 of the Andean Community of Nations on the treatment of foreign capital, trademarks, patents, licenses, and royalties; Decision 486 on the standard system of industrial property or Decisions 632 and 689 deriving from the 486 have shown a looser defense in regional terms, but a highly incisive stance on compatibility with other international standards and bilateral treaties. They seemed to have greater coercive force on the part of industrialized countries. To conclude this section and see the risk that there has been a lack of clear regulations regarding the protection of industrial property in the case of Monsanto. The situation is that Monsanto went to a large number of countries where there were no deep intellectual property rights and applied conditions from its country of origin. It is essential to show the limitations of unspecific regulations and avoid the servility of politics to large transnationals resulting from an error in delimitation. As Marie-Monique (2008) explains, Monsanto took advantage of several legal loopholes to generate costly patent lawsuits and ban farmers from using their seeds for next year's crop because they contain the famous Roundup Ready (patented by Monsanto). As seen superficially in this example, when there is no precise regulation that operates under fair parameters, it is even possible for a company to sue farmers for continuing millennial practices and trying not to generate a high degree of waste. The Latin American State has a long way to protect the rights prescribed in its constitutions if this excellent business power is compounded by conditioning, corruption, and government interference. 


\subsection{Evaluation of the Organic Code of the Social Economy of Knowledge (Código Orgánico de la Economía Social de los Conocimientos, la Creatividad y la Innovación)}

For evaluating which model of intellectual property protection should be used in Ecuador, it has been fundamental to understand the situation after the conspicuous "Código Ingenios" has been adopted. Due to extension issues, it will not be possible to evaluate in-depth each of the components of the code above, however, after a thorough review of the surrounding literature and the code itself, the central points can be discussed and evaluated from deontology. of Intellectual Property.

The "Codigo Ingenios" links in the first instance a common approach through a large number of articles (especially in the first book) that show principles concerning this research:

a) the socialization of knowledge;

b) the protection of creations with an approach of dissemination of ideas; 3) state support and investment as an engine of innovation;

c) the diffusion and universalization of the Internet as a breakdown of economic barriers to knowledge;

d) the drive for national inventors and small-scale discoveries; and

e) the idea of free software to achieve more widespread access or strengthening of aid to researchers who have high potential but no resources (National Assembly, 2016).

These arguments show the transparent approach of the code. If we compliment them with: the intention to achieve greater access of the population to patent drugs, the fight against scheduled obsolescence (with short-lived technological products ). The notion of reverse mining for the recovery of knowledge by people of limited resources or companies with environmental responsibility. Also, the assurance of the rights of ancestral peoples and the acquisition of knowledge through 
their historical practices. Then, the fight against biopiracy by the major pharmaceutical companies related to the intangible heritage of ancestral peoples and the policies of greater control over the appropriation of knowledge by foreigners corroborates all that has been said so far regarding this leap in the approach to the protection of Industrial Property rights ( Ramirez, 2014).

Everything set out here seems to be in line with the postulates of Professor Chang (2001) and also seems to be in excellent harmony with the progressive halo of the 2008 constitution, however, as stated in the first section of this section, the claim is the normative evaluation from the being and the duty to be able to formulate a suitable and applicable policy.

The behavior of Ecuador's GDP since the issuance of the so-called "Código Ingenios" has not been positive in the slightest and, even with the exclusion of exogenous factors, technological development and innovation have not had any peak. It is prudent to emphasize that empirical evaluation can only be given in the long run and through rigorous mathematical models that exclude non-excluded third parties; however, by using a deductive method in the next paragraph, the hypothetical scope will be explored based on a counterfactual analysis from the optimization ideal.

In the remainder of this section, we will analyze what would have happened with the "Código Ingenios" in another institutional context, in the light of the institutional theory of Acemoğlu (2012) ceteris paribus the Ecuadorian case. Had there been a healthy institutional system, actual State without economic "prebendas," with political independence and with the instrumentation of technical and objective analyzes in decision-making, the regulations, and flexibilities of this code would have had a much more significant and positive result, in aggregate terms. To try to complicate the questioning and talk about the relevance of the code, a brief control of legality and constitutionality will be made with just a legal body and a 
constitutional variable. As for the legal body, the Organic Law of Regulation and Control of Market Power will be mentioned, which contrasts the express prohibition of the monopolistic exercise (except for collective interest) with the monopoly granted with a patent. It is critical to understand that a patent is indeed a monopoly by definition, but that this monopoly could have a social utility in certain circumstances, so with a broad interpretation, this can be ruled out. As for the Constitution of the Republic of Ecuador (2008), the idea of a popular and solidarity economy (article 283) would be embroiled in a possible contradiction with the defense of patents. However, again the broad meaning of this defense must be understood. Moreover, it must be emphasized that as seen in previous sections, this defense can help the development of new technologies, and this, in a way, derived from the holistic development discussed in the introductory section.

The final idea that is going to be limited concerning the "Codigo Ingenios" is that, although of very concrete foundations, it is due to connect of the better way with the productive thing with the investigative thing with the eagerness that does not exist a dependence either of the production or of the research and give more excellent stability to the investor, researcher, and producer as Ramírez (2014) rightly argues.

\subsection{Some contemporary alternatives to the traditional defense of Industrial Property and some critical views}

Some alternatives to the traditional forms of protection of Industrial Property rights will be briefly stated. Before that, it is worth mentioning that both right-wing branches (such as the Austrian school with Hayek and Von Mises) and leftwing branches (such as anarchists and Marxists) argue that alternative means should be developed for the defense of industrial property. Fall into authoritarian controls of other people's property. 
Within the previous line of ideas, various mechanisms have been discussed to ensure that trademarks, patents, and licenses operate efficiently, but no longer from an exclusive logic, but the inclusion of all dissemination and channeling mechanisms of knowledge.

According to Buitrago \& Castañeda (2011), there are innovative alternatives for the promotion of research and the protection of inventors' rights. Copyleft is proposed as an option to share and reuse the works through free licenses, provided that the practice is maintained free of charge. Another alternative is the creative commons that seek to maintain the recognition of the authors, not to give a commercial use, not to allow derivatives of the works, to maintain the status of free access, but to break the scheme of the private cognitive property. Whatever the path, it is clear that there are alternatives and could be exploited in various ways in the Ecuadorian case, although it should be noted that this does not limit the maintenance of a parallel legal system under more permissive dissemination modalities.

\section{CONCLUSIONS}

This miscellaneous will end with some critical outputs. In the first instance, it is warned that the excessive protection of intellectual property can be a mechanism for appropriating monopolistic profits, so the State must regulate that incisively. Then, it is mentioned that in order to develop dynamic competitiveness in the context of the great defense of intellectual property, much higher percentages of GDP must be invested in science and technology. Besides, it is argued that the approach must be long-term and that policies must seek strategic spaces for action and partnership.

Also, patents must be prevented from becoming legal barriers and dominant positions held by transnational corporations or large corporations. It is argued that patents are positive in the absolute sense of being made with local technology and product, and the ethical dimension is not 
settled due to a double standard of the decision of developed countries. Consequently, it is emphasized that specific sectors need more care, such as medicines and commodities, for human consumption.

Thus, there is a strong influence of transnationals in politics, and negotiations are unbalanced in favor of large transnationals, which must be broken if objective and effective legislation is reached. Regional union and multilateralism are critical solutions to the global logic on a more level playing field. It is consistent with the idea of fitting piracy in all contexts, although the personal and non-profit use of various digital content that advanced international regulations protect must not be severely restricted.

States are urged to promote judicial agility to lower costs and facilitate inevitable litigation that can be complicated and cumbersome. It is so since it is considered that the creation of public libraries with greater access can reduce the technological and cognitive gap within society and worldwide. States must also defend consumer rights and fight against monopolies that may harm them because states can become engines of growth and development with appropriate policies and high investment in $R \& D$. There must be a robust institutional framework that guarantees compliance and avoids the violation of Industrial Property rights. Sixteenth, foreign investment must be attracted to fair and equitable terms without violating the rights of citizens.

Developing countries secure less intellectual property rights due to their need to exploit emerging technology as soon as possible. Furthermore, economic growth will not be equated with holistic development, so the excessive defense of intellectual property rights can lead to investment and economic growth, but increasing inequality and social problems do not lead to real development. 
The "Código Ingenios" has brought exciting proposals from the duty to be but has been limited by an application without due rigor. The standard approach to knowledge is consistent with the constitution of Ecuador and various internal norms. The history shows that state intervention has had favorable results, especially for the correction of externalities.

Finally, as a general conclusion of the work, it is essential to mention that Ecuador must seek a pragmatic vision and adopt policies that guarantee on the one hand the protection of the rights of companies and industrial inventors, but on the other hand that guarantees equity in the distribution of benefits and high social justice.

\section{REFERENCES}

Acemoglu, D. \& Akcigit, U. (2012). Intellectual property rights policy, competition, and innovation. Journal of the European Economic Association, 10 (1), 1-42. Doi: http://dx.doi.org/10.1111/j.1542-4774.2011.01053.x

Acemoglu, D., Johnson, S. \& Robinson, J. (2005). Institutions as a fundamental cause of long-run growth. In Aghion, P. and S.N. Durlauf (eds), Handbook of Economic Growth, Vol. 1. Amsterdam: Elsevier, 385-472.

Organización de las Naciones Unidas (1947). Acuerdo General sobre aranceles aduaneros y comercio. Obtenido de https://www.wto.org/spanish/docs_s/legal_s/gatt47. pdf

ANDES. (2016). Con el código ingenios, Ecuador tendrá un nuevo modelo de gestión de los conocimientos y de producción. Recuperado de: http://www.andes.info.ec/ es/noticias/codigo-ingenios-ecuador-tendra-nuevomodelo-gestion-conocimientos-produccion.htmlASLE 
Anguita, L. (2016). Tensiones entre la propiedad intelectual y la propiedad ordinaria. Editorial: Editorial Reus, S.A., Madrid, España.

Asamblea Nacional del Ecuador (2016) Código Orgánico de la Economía Social de los Conocimientos. Registro Oficial Suplemento 899 de 09-dic.-2016. Quito: Ecuador

Boldrin, M., \& Levine, D. (2008). Against Intellectual Monopoly. New York: Cambridge University Press

Bordieu, P. (2001). Poder, derecho y clases sociales. (3ra. ed.). Catedras RFDV. Madrid, España.

Boyle, J. (2003). The second enclosure movement and the construction of the public domain. Law and contemporary problems, 66 (1-2).

Bregman, R. (2017) Utopía para Realistas. Barcelona, España: Salamandra Disponible en: https://www.ehu.eus/ documents/6902252/7163304/Utopia-para-realistasrutger-bregman.pdf/6ef0883c-3c83-8a03-e42cofdefe54358d

Buitrago, J., \& Castañeda, M. (2011). La función social como límite a la propiedad intelectual. Bogotá D.C.: Mimeo.

Castro, J. (2009). La propiedad industrial. Bogotá: Universidad Externado de Colombia.

CEPAL (2008) Generación y protección del conocimiento: propiedad intelectual, innovación y desarrollo económico. México D.F., México: Mundi-Prensa.

Chang, H-J (1998). Globalization, Transnational Corporations, and Economic Development' in D. Baker, G. Epstein, and R. Pollin (eds.), Globalisation and Progressive Economic Policy, Cambridge: Cambridge University Press. 
Chang, H-J (2001) Intellectual Property Rights and Economic Development - Historical Lessons and Emerging Issues, Journal of Human Development 2(2)

Chang, H-J (2002) Kicking Away the Ladder - Development Strategy in Historical Perspective, London: Anthem Press

Chen, Y. \& Puttitanun, T. (2005). Intellectual property rights and innovation in developing countries. Journal of Development Economics, (78), 474493. Doi: http:// dx.doi.org/10.1016/j.jdeveco.2004.11.005

Correa, C. (2008). Intellectual Property Rights and Inequalities in Health Outcomes. Globalization and Health Knowledge Network, 28.

El Telégrafo (2016) Entrevista Ha Joon Chang. Obtenido el 16 de Noviembre de 2019 de: https://www.eltelegrafo.com. ec/noticias/economia/4/el-codigo-ingenios-es-unamuy-buena-ley-para-resolver-algunos-problemas

Foucault, M. (1981) Un diálogo sobre el poder. Madrid, España: El libro de bolsillo Alianza Editorial

Gerring, J. (2004) What is a Case Study and What is it Good for? Boston, Estados Unidos: American Political Science Association

Gómez-Valenzuela, V. (2018) Relación entre propiedad intelectual, innovación y desarrollo: evidencias de datos de panel. Ciencia y Sociedad, vol. 43, núm. 1.

Hernández, R. (2014) Metodología de la Investigación (6ta ed.). México D.F., México: McGraw-Hill Editores S.A.

Leavy, P. (2014) The Oxford Handbook of Qualitative Research. Nueva York, Estados Unidos: Oxford University Press 
Machlup, F. y Penrose, E (1950). The Patent Controversy in the Nineteenth Century, Journal of Economic History, 10 (1).

Marie-Monique, R. (2008) El mundo según Monsanto. E-Pub base $\mathrm{r} 1.2$

Mayol, A. (2017). Autopsia, ¿De qué se murió la élite chilena? Santiago de Chile: Catalonia Instituto Chileno de Propiedad Intelectual (s.f.) Conceptos fundamentales sobre la Propiedad Intelectual. Recuperado el 17 de noviembre de 2019 de la siguiente fuente: https://www. inapi.cl/portal/institucional/600/fo-article-1192.pdf

Mejía, E \& Ayaviri, D. (2018) Avances y perspectivas de la propiedad intelectual en América Latina y el Caribe. Revista Espacios, Vol. $39 \mathrm{~N}^{\circ} 41$.

Negri, A. y Hardt, M. (2011). Commonwealth. Madrid: Akal

Ojeda, S., \& Jhair, A. (2011). Teorías del Derecho de la Propiedad Intelectual. Universidad Nacional Federico Villareal, 26.

OMPI (2018). Estadísticas de propiedad intelectual, http:// www.wipo.int/ipstats/es/

Organización Mundial de la Propiedad Intelectual (s.f.) ¿Qué es la Propiedad Intelectual? Publicación 450. Accedido el 09 de noviembre de 2019 de la siguiente fuente: https:// www.wipo.int/edocs/pubdocs/es/intproperty/450/ wipo_pub_450.pdf

Organización Mundial de la Propiedad Intelectual. (1967). Convenio que establece la Organización Mundial de la Propiedad Intelectual. Obtenido de https://www.wipo. int/treaties/es/text.jsp?file_id=283997

Organización Mundial de la Propiedad Intelectual. (2018). ¿Qué es la OMPI? Obtenido de https://www.wipo.int/ about-wipo/es/ 
Organización Mundial de la Propiedad Intelectual. (2018). Madrid - El Sistema internacional de marcas. Obtenido de https://www.wipo.int/madrid/es/

Organización Mundial de la Propiedad Intelectual. (s.f.). ¿Qué es la propiedad intelectual? Ginebra, Suiza.

Organización Mundial del Comercio. (2018). ¿Qué es la OMC? Obtenido de https://www.wto.org/spanish/thewto_s/ whatis_s/whatis_s.htm

Organización Mundial del Comercio. (2018). Propiedad intelectual: protección y observancia. Obtenido de https://www.wto.org/spanish/thewto_s/whatis_s/ tif_s/agrm7_s.htm

Pazos, R. (2016). El Código Ingenios y su construcción colaborativa. En R. Ramírez (ed.), Universidad urgente para una sociedad emancipada (pp. 541- 564). Quito: SENESCYT-IESALC

Polanyi, K. (1992). La gran transformación: los orígenes políticos y económicos de nuestro tiempo. México: FCE.

Porter, M (1991) La ventaja competitiva de las naciones. Buenos Aires, Argentina: Vergara Editor S.A

Programa de las Naciones Unidas para el Desarrollo (2010) Informe sobre el Desarrollo Humano 2010. Nueva York, Estados Unidos: Mundi-Prensa

Ramírez, R. (2014). La virtud de los comunes: de los paraísos fiscales al paraíso de los conocimientos abiertos. Quito: Abya-Yala.

Schiff, E. (1971) Industrialisation without National Patents - the Netherlands, 1869-1912 and Switzerland, 1850-1907, Princeton: Princeton University Press. 
Stiglitz, J. E. (2008). Economic foundations of intellectual property. Duke Law Journal, 57 (6), 1693-1724.

Tejedor, R. Gil, M. \& Tejedor, J. (2016) Derechos de Propiedad Intelectual (DPI) y crecimiento económico: una revisión

The Competitive Intelligence Unit (2011) Propiedad Intelectual, Motor de Crecimiento y Desarrollo. Obtenido de: https://static1.squarespace. com/static/587fdc951b10e30ca5380172/t/5 8d0a98815d5dbcf5a39f54c/1490069948995/ Microsoft+Propiedad+Intelectual.pdf

Valcárcel, M. (2006) Génesis y evolución del concepto y enfoques sobre el desarrollo. Lima, Perú: Pontificia Universidad Católica Recuperado el 13 de noviembre de 2019 de la siguiente fuente: https://www.uv.mx/mie/ files/2012/10/SESION-6-Marcel-Valcarcel-DesarrolloSesion6.pdf

Vandana, S. (2003). ¿Proteger o expoliar? Los derechos de propiedad intelectual, Hurope, S.l., Barcelona, España.

Vargas, J. (2010). La propiedad industrial y su importancia en el comercio, Dirección de Relaciones Internacionales del Instituto Mexicano de Propiedad Industrial, México D.F., México

World International Property Organization (2019) The Geography of Innovation: Local Hotspots, Global Networks. Geneva 20, Switzerland

Wu Ming (2005). "Copyright y maremoto", en Contra el copyright. México D.F.: Tumbona. 
Received: $21 / 11 / 2019$

Approved: 21/06/2020

Raúl Alexander Velasco Chávez

Independent legal researcher

Email: valex1600@gmail.com

City: Quito

Country: Ecuador 
